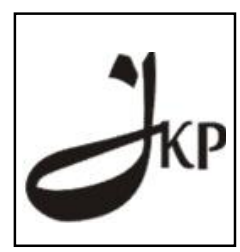

Jurnal Konseling dan Pendidikan

ISSN Cetak: 2337-6740 - ISSN Online: 2337-6880

http://jurnal.konselingindonesia.com

Volume 1 Nomor 1, Februari 2013, HIm 23-26

MULTIKARYA KONS

Info Artikel:

Diterima 12/01/2013

Direvisi 20/02/2013

Dipublikasikan 01/03/2013

\title{
Stategi Intervensi Konseling Untuk Mengatasi Kecemasan Siswa
}

\author{
Tri Leksono ${ }^{1 *}$
}

${ }^{1}$ IKIP Veteran Semarang

\begin{abstract}
Abstratc
Dewasa ini, ditengarai bahwa banyak siswa di SMP dan SMA di Kab Magelang yang mengalami masalah dalam kehidupan pribadinya; salah satu diantaranya ialah masalah kecemasan. Apabila siswa mengalami kecemasan berlebihan, biasanya tidak mampu mengatasinya sendiri. Sebagai akibatnya siswa tersebut selalu mengalami kegagalan yang menyebabkan ia menjadi pesimis, mempunyai harga diri kurang, putus asa, frustasi, tak dapat bertindak efektif dan tak dapat mencapai prestasi optimal. Untuk mengatasi kecemasan yang dialami siswa SMP dan SMA di Kabupaten Magelang perlu dirancang dan diterapkan Strategi Intervensi Konseling yang tepat, tingkat kecemasan yang dialami para siswa dapat diturunkan secara maksimal dengan cara mendesain Strategi Intervensi Konseling dengan teknik Cognitive Restructuring (CR) dan Systematic Desensitization (SD) yang efektif diterapkan untuk mengatasi kecemasan para siswa SMP dan SMA di Kabupaten Magelang. Dengan melakukan kegiatan sebagai berikut: 1) menganalisis tingkat kecemasan para siswa SMP dan SMA di Kabupaten Magelang, 2) mengidentifikasi factor penyebab timbulnya kecemasan siswa, 3) menganalisis terori-teori yang mendukung pemecahan masalah kecemasan, dan 4) mendesain Strategi Intervensi Konseling yang cocok digunakan untuk mengentaskan kecemasan siswa. Sampel penelitian dipilih secara purposive random sampling. Instrumen penelitian yang digunakan adalah Skala Kecemasan (Manivest Anxiety Scale) dan angket evaluasi perlakuan. Desain eksperimen yang digunakan adalah pretest-postest control group desain. Penelitian ini diharapkan dapat menciptakan sebuah Strategi Intervensi Konseling yang cocok digunakan untuk mengurangi tingkat kecemasan siswa SMP dan SMA
\end{abstract}

Keyword: SIK, Kecemasan, CR, SD.

Copyright (C) 2013 IICE - Multikarya Kons - All Rights Reserved Indonesian Institute for Counseling and Education (IICE) Multikarya Kons

\footnotetext{
*Telp dan/atau Alamat Email Koresponden :

${ }^{1}$ Email: kokok_abkin@yahoo.co.id
} 


\section{PENDAHULUAN}

Siswa merupakan titik sentral dalam keseluruhan sistem pendidikan di sekolah. Segala daya dan dana diadakan untuk mengembangkan siswa ke arah terbentuknya manusia seutuhnya seperti yang dimaksud UU Sistem Pendidikan Nasional tahun 2003. Oleh karena itulah sekolah di samping menyajikan kurikulum yang menyangkut ilmu, tehnologi, dan seni, juga menyelenggarakan kegiatan pembinaan kesiswaan. Salah satu bentuknya adalah layanan bimbingan konseling. Dewasa ini, ditengarai bahwa banyak siswa di SMP dan SMA di Kab Magelang yang mengalami masalah dalam kehidupan pribadinya; salah satu diantaranya ialah masalah kecemasan. Apabila siswa mengalami kecemasan berlebihan, biasanya tidak mampu mengatasinya sendiri. Sebagai akibatnya siswa tersebut selalu mengalami kegagalan yang menyebabkan ia menjadi pesimis, mempunyai harga diri kurang, putus asa, frustasi, tak dapat bertindak efektif dan tak dapat mencapai prestasi optimal.

Siswa yang mempunyai tingkat kecemasan yang tinggi akan merasakan bahwa kegiatan belajar mengajar di sekolah merupakan suatu kegiatan yang mengancam dirinya, Hal ini akan menyebabkan konsentrasi belajarnya terganggu yang pada akhirnya dapat mengakibatkan prestasi belajarnya menurun. Pada gilirannya mereka tidak mampu mengembangkan potensi dirinya secara maksimal, tidak suka belajar, bergabung dengan kelompokkelompok remaja yang ingin bebas dan bersenang-senang sehingga menghasilkan sumber daya manusia yang kurang berkualitas. Dengan demikian, masalah kecemasan yang dialami siswa SMP dan SMA perlu diketahui secara dini dan diupayakan mengatasinya semaksimal mungkin, Mengingat banyaknya siswa SMP dan SMA yang mengalami kecemasan dalam hidupnya, perlu kiranya dicarikan upaya pemecahan yang bisa membantu mereka menghindari kecemasan yang menggorogoti dirinya sendiri. Salah satu cara yang mungkin bisa digunakan untuk membantu mengatasi kecemasan siswa di SMP dan dan SMA adalah Strategi Intervensi Konseling (SIK) dengan menerapkan model Cognitive Restructuring (CR), dan Systematic Desensitization (SD) (Braid, 1981; Bower, 1986; Burgoon dan Rufner, 1978; Freimuth dalam Baker, 1982; Whitman dan Boose, 1983). Dengan menerapkan SIK ini, kecemasan yang dialami siswa dapat diatasi secara maksimal

\section{TUJUAN}

Penelitian ini bertujuan untuk membandingkan tingkat kecemasan siswa sebelum dan sesudah diberi intervensi dan strategi konseling yang berupa Cognitive Restructuring (CR) dan Systematic Desensitisasi (SD). Dan membandingkan keefektifan intervensi dan strategi konseling yang berupa Cognitive Restructuring (CR) dan Systimatic desensitization (SD) yang dikombinasikan, dengan yang tanpa dikombinasikan untuk menangani kecemasan siswa

\section{METODOLOGI}

Dalam penelitian ini menggunakan rancangan penelitian eksperimen dengan pretest-posttest control group design. Dengan demikian desain penelitian ini dapat digambarkan sebagai berikut.

\begin{tabular}{|llll|l}
\hline & $\mathrm{YI}$ & $\mathrm{X} 1$ & $\mathrm{Y} 2$ & $\mathrm{~K} 1$ \\
$\mathrm{R}$ & $\mathrm{Y} 1$ & $\mathrm{X} 2$ & $\mathrm{Y} 2$ & $\mathrm{KE} 2$ \\
& $\mathrm{Y} 1$ & $\mathrm{X} 12$ & $\mathrm{Y} 2$ & $\mathrm{KE3}$ \\
& $\mathrm{Y} 1$ & $\sim \mathrm{X}$ & $\mathrm{Y} 2$ & $\mathrm{KK}$ \\
\hline
\end{tabular}

Keterangan :

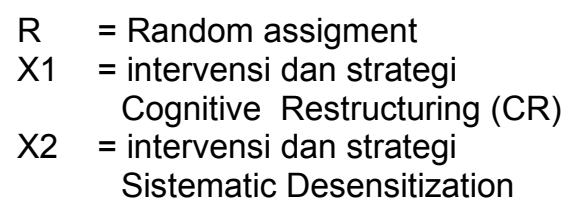

(SD) 
Jurnal Konseling dan Pendidikan

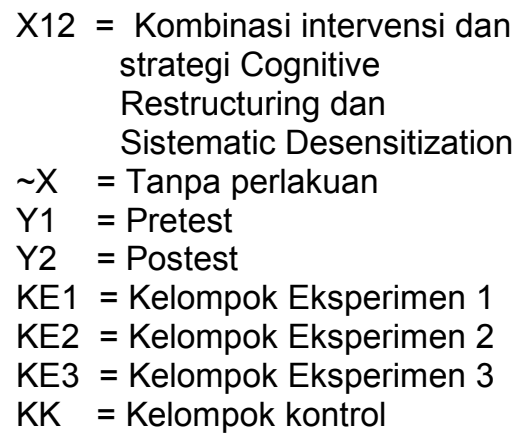

Pada dasarnya ada 5 (lima) tahap kegiatan yang perlu dilakukan dalam mengembangkan suatu model atau strategi, yaitu analysis, design, development, implementation, dan evaluation yang disingkat dengan "ADDIE" model. Populasi penelitian ini adalah: seluruh siswa SMP dan SMA kabupaten Magelang yang mengalami kecemasan. Sampel penelitian adalah sebagian anggota populasi tersebut yang diambil dengan teknik cluster random sampling. selanjutnya semua siswa kelas VII dan IX untuk SMP dan kelas X dan XII untuk SMA di sekolah tersebut di minta untuk mengisi MAS (Manifest Anxiety Scale) sehingga diketahui siswa yang mengalami kecemasan. Langkah selanjutnya memilih siswa yang mengalami kecemasan secara acak sehingga terpilih 20 siswa, yang terdiri 10 siswa SMP dan 10 siswa SMA sebagai subyek penelitian.

Pemilihan 20 siswa sebagai sampel penelitian ini didasari alasan bahwa dibutuhkan waktu yang cukup lama untuk memberi perlakuan terhadap 1 orang klien minimal 6 kali pertemuan, karena waktu yang disediakan untuk penelitian ini terbatas maka yang dapat diberi perlakuan sekitar 20 siswa.

Siswa yang terpilih menjadi subyek penelitian sebanyak 20 orang dibagi secara random menjadi 5 kelompok, masing-masing 10 siswa SMP dan 10 siswa SMA. Satu kelompok sebagai kelompok yang mendapat perlakuan CR, satu kelompok sebagai kelompok yang mendapat perlakuan SD, satu kelompok sebagai kelompok yang mendapat perlakuan CR dan SD, serta satu kelompok merupakan kelompok kontrol (waiting list) yaitu kelompok yang tidak memperoleh perlakuan saat itu, tetapi memperoleh perlakuan setelah eksperimen selesai.

\section{HASIL PENELITIAN}

Hasil penelitian ini memaparkan hasil uji hipotesis yang diajukan. Hipotesis yang diajukan meliputi: Pengujian Hasil dengan menggunakan desain pretest-postes control group design pengujian dilakukan 2 (dua) kali, dapat dinyatakan efektif terlihat perbedaan bahwa nilai rata-rata uji $2(73,18)$ lebih besar dari uji $1(71,17)$, dengan $r$ hitung $(6,39)$ lebih besar dari $r$ tabel $(2,00)$, kesimpulan model efektif baik pada tingkat SMP maupun SMA terlihat dari hasil nilai yang cenderung lebih tinggi, tapi perlu diadakan penelitian lebih lanjut karna keterbatasan waktu, peningkatan kemampuan konselor dalam penggunaan SIK, biaya dan kesempatan penelitian di lapangan.

\section{DAFTAR PUSTAKA}

Blackburn \& Davidson, 1990, Terapi Kognitif, Jakarta: Rajawali.

Blackham, G. 1977, Counseling:theory, process, and practice. Belmont, California: Wadsworth Publising Company.

Burns, D. D 1988. Terapi kognitif: Pendekatan baru bagi penanganan depresi (alih bahasa Santosa), Jakarta : Erlangga.

Bootzin, R. S, 1991, Behavior Modifikation and Therapy: An Introduction. Cambridge: Winthrop Publisher.

Burham, S. 1997, Emosi dalam Kecemasan. Jakarta: BPK. Gunung Mulia.

Morgan, H. C dan Morgan, M. H., 1989. Segi Praktis Psikiatri. Jakarta: Binarupa Aksara. 
Jurnal Konseling dan Pendidikan

http://jurnal.konselingindonesia.com

Vol. 1 No. 1, Februari 2013. hlm. 23-26

Utami, M. S, 1991, Efektivitas Relaksasi dan Terapi Kognitif untuk Mengurangi Kecemasan Berbicara di Muka Umum, Berkala Penelitian Pasca Sarjana UGM, 4, 311 - 321.

Warsiki, E. \& Lestari S., 1981. Kecemasan pada Anak, remaja, serta Peranan Orangtua dan Lingkungan. Surabaya: PNPNCH. Jawa Timur. 